\title{
PENGARUH PERILAKU MENONTON TAYANGAN KEKERASAN TERHADAP AGRESIVITAS PENONTON REMAJA (Studi Eksplanatif Menonton Tayangan Kekerasan dalam Film "Joker" Terhadap Agresivitas Penonton Remaja di DKI Jakarta)
}

\author{
Anna Rifa Nabila ${ }^{1^{*}}$, Mohamad Syahriar Sugandi ${ }^{2}$ \\ 1,2 Prodi S1 Ilmu Komunikasi, Fakultas Komunikasi dan Bisnis, Telkom University \\ *Penulis korespondensi; Email: ${ }^{1}$ annarifanabila@gmail.com; ${ }^{2}$ mohsyahriar@gmail.com
}

\begin{abstract}
ABSTRAK
Penelitian ini bertujuan untuk mengetahui seberapa besar pengaruh perilaku menonton tayangan kekerasan terhadap sikap agresivitas penonton remaja di DKI Jakarta. Variabel independent yang digunakan pada penelitian ini yaitu Perilaku Menonton (X) dengan dimensi Kemampuan memilih, Kesengajaan, Keyakinan, Keterlibatan, dan Pemanfaatan. Variabel dependent yang digunakan yaitu Agresivitas (Y) dengan dimensi Agresi Fisik, Agresi Verbal, Agresi Permusuhan, Agresi Kemarahan. Penelitian ini menggunakan metode kuantitatif, dengan jenis penelitian eksplanatif, uji normalitas, uji regresi linier sederhana, koefisien determinasi dan uji hipotesis. Teknik sampling yang digunakan dalam penelitian ini adalah nonprobability sampling, yaitu quota sampling, dan menggunakan rumus tabel Krejcie-Morgan, dengan jumlah 100 responden. Hasil uji hipotesis menunjukan bahwa perilaku menonton tayangan kekerasan memiliki pengaruh yang signifikan terhadap sikap agresivitas penonton remaja di DKI Jakarta, hal tersebut dibuktikan dengan t hitung (4.584) > t tabel (1.664) dan hasil koefisien determinasi menunjukan bahwa perilaku menonton tayangan kekerasan memiliki pengaruh sebesar 65,93\% terhadap sikap agresivitas penonton remaja di DKI Jakarta. Sedangkan sebesar 34,07\% sikap agresivitas dipengaruhi oleh faktor lain yang tidak diukur dalam penelitian ini.
\end{abstract}

Kata kunci: Perilaku Menonton, Agresivitas, Tayangan Kekerasan

\begin{abstract}
This study aims to determine how much influence the watching behaviour violent shows on the aggressiveness of teenagers in DKI Jakarta. The independent variables used in this study are watching behavior (X) with selectivity, Intentionally, Imprevious Influence, Involvement, Utilitarianism. The dependent variable used is Aggressiveness (Y) with dimensions of Physical Aggression, Verbal Aggression, Hostile Aggression, Anger Aggression. This research uses quantitative methods, with the type of explanatory research, normality test, simple linear regression test, coefficient of determination and hypothesis testing. The sampling technique used in this study is nonprobability sampling, namely quota sampling, and using the Krejcie-Morgan table formula, with a total of 100 respondents. Hypothesis test results show that the behavior of watching violent shows has a significant effect on the aggressiveness of adolescent viewers in DKI Jakarta, this is evidenced by $t$ arithmetic $(4,584)>t$ table $(1,664)$ and the results of the coefficient of determination indicate that the behavior of watching violent shows has an effect of $65.93 \%$ of the attitude of the aggressiveness of teenagers in DKI Jakarta. While $34.07 \%$ of aggressiveness is influenced by other factors not measured in this study.
\end{abstract}

Keywords: Watching Behavior, Aggressiveness, Violent Impressions.

\section{PENDAHULUAN}

Film merupakan salah satu media massa untuk hiburan masyarakat yang banyak diminati oleh masyarakat, bahkan pertumbuhan penonton film di Indonesia pun terus meningkat setiap tahunnya, menurut data yang dilansir katadata.com pada akhir tahun 2017 penonton film Indonesia mencapai 42,7 Juta penonton yang naik secara signifikan dari 16 Juta penonton di tahun 2015. Penambahan jumlah penonton bioskop tersebut pun membantu meningkatkan pendapatan sebesar $10.09 \%$ dari tahun 2016. Pada tahun 2018, pertumbuhan penonton pun naik sebesar 20\% mulai dari Januari hingga Agustus 2018 jumlah penonton yang tercatat sebanyak 36,3 Juta. Di tahun 2019 peningkatannya meningkat sebesar $230 \%$.

Dengan adanya data peningkatan penonton di Indonesia ini mengartikan tingginya minat masyarakat untuk mendapatkan hiburan dari film. Namun, film kini sudah sangat berkembang tidak hanya berisikan hiburan semata banyak hal-hal yang terkandung dalam film sesuai genre yang ada salah satunya yakni tayangan kekerasan. Tayangan ke- 
kerasan di dalam film uniknya bisa meningkatkan pemasukan yang lebih menguntungkan, hal ini disebabkan orang menganggap kekerasan itu indah dan mampu menciptakan suatu sensasi yang nikmat (Haryatmoko, 2017:124).

Menurut data yang dilansir melalui Idn.times.com (diakses tanggal 27 Januari 2020 pukul 12.50 WIB) dijelaskan salah satu film dengan Rating $\mathrm{R}$ atau Restricted yang saat ini sedang ramai di kontroversialkan adalah film berjudul "Joker". Film ini diberikan symbol terbatas karena didapatkan penggunaan bahasa dan tindakan yang belum layak disaksikan mereka yang masih berusia dibawah 17 tahun. Film "Joker" pun menjadi pemimpin film dalam kategori film dengan pendapatan terbesar sepanjang masa dengan film rating $\mathrm{R}$ atau dewasa.

Diketahui bahwa film "Joker" masuk dalam kategori film dengan pendapatan terbesar yaitu 11,8 triliun dengan rating film R. Pendapatan terbesar itu pun datang khusus untuk film "Joker" tanpa ada pembayaran keterikatan dengan Iklan yang ditayangkan pada bioskop-bioskop. Pro dan kontra pun terjadi didalam masyarakat ketika penayangan film "Joker", Pro dari film "Joker" ini dapat dilihat dari pendapatan film terus meningkat yang berarti para penonton menyukai film ini dan penasaran dengan alur ceritanya. Beberapa penonton pun memuji pembuatan dari Film "Joker" yang diperankan oleh Joaquin Phoniex hingga mendapatkan beberapa penghargaan.

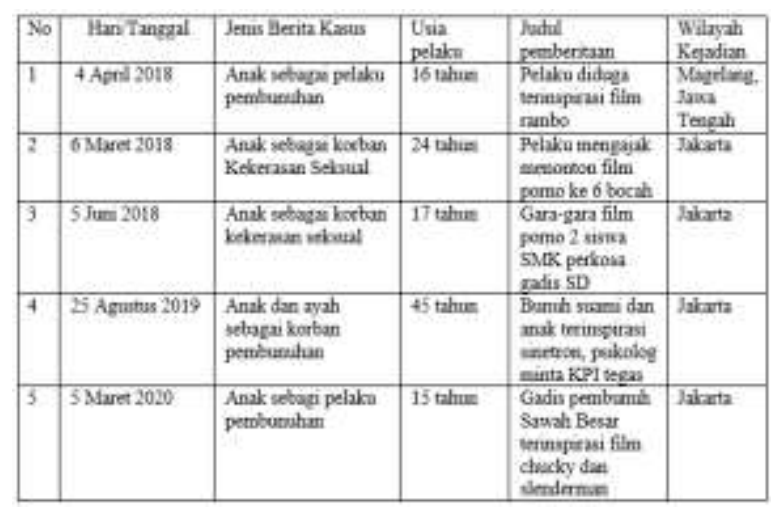

Gambar 1 .Data kekerasan akibat pelaku melihat tayangan kekerasan (Sumber: https://bankdata.kpai.go.id)

Adanya pelaku kekerasan usia remaja yang diakibatkan pelaku terpengaruh oleh tayangan yang berisikan kekerasan. Dari data tersebut terlihat adanya usia yang masih dibawah 17 tahun yang tidak patuh dengan aturan rating film yang sudah di atur oleh lembaga film. Sehingga berdampak pada psikologisnya yang ingin meniru adegan dari film kekerasan yang telah ditontonnya.
Mayoritas bioskop berada di pulau Jawa yaitu 183 bioskop dengan 988 layar atau sekitar 70\% dari total keseluruhan layar. Bioskop terbanyak terdapat di DKI Jakarta $^{4}$

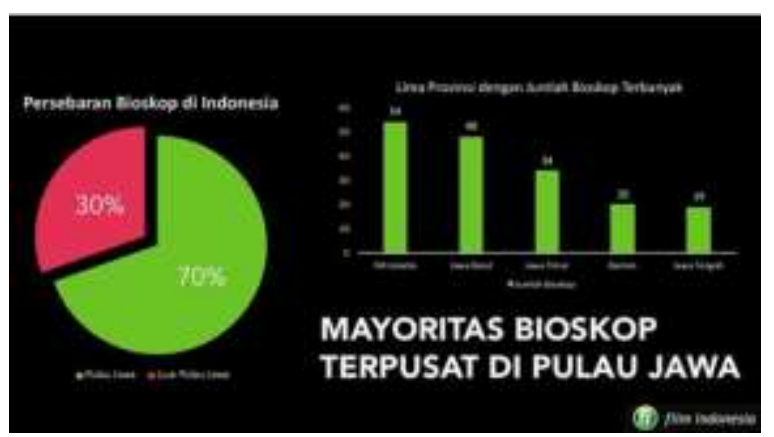

Gambar 2. Jumlah Bioskop di Indonesia 2018 (Sumber: http://filmindonesia.or.id/)

Menurut Nando (2011) di dalam jurnal penelitian terdahulu menjelaskan bahwa film yang berunsur kekerasan atau horor mampu meningkatkan potensi perilaku agresi remaja yang mendorong tindakantindakan untuk mencelakakan orang lain. Sebagian besar penelitian terdahulu menggunakan teori S-O-R dimana penonton akan mudah menstimulus tayangan yang mereka tonton dengan cepat. Namun pada perkembangan teori adanya perubahan dimana penonton akan lebih aktif untuk memilih tayangannya, sehingga peneliti melihat dari sudut pandang perilaku penonton dengan menggunakan teori kultivasi dimana melihat pengaruh kepada remaja yang menonton tayangan kekerasan dalam film Joker dengan intensitas menonton lebih dari satu kali untuk melihat adanya pengaruh.

Sehingga dengan didasari hal-hal yang sudah dijelaskan di atas, maka peneliti melakukan penelitian yang berjudul "Pengaruh Menonton Tayangan Kekerasan Terhadap Agresivitas Penonton (Studi Eksplanatif Menonton Tayangan Kekerasan dalam Film "Joker" Terhadap Agresivitas Penonton Remaja di DKI Jakarta)"

\section{TINJAUAN PUSTAKA}

\subsection{Teori Behaviorisme}

Teori behaviorisme hanya menganalisis perilaku seseorang yang dapat diukur. Teori ini pun menjelaskan bahwa setiap manusia tidak membawa sifat atau perilaku dari lahir melainkan manusia memiliki sifat atau perilaku dengan cara menstimulus segala hal yang ada di lingkungan sekitarnya. Teori ini dikemukakan oleh John B Watson pada tahun 1913. Hal tersebut termasuk dalam segala aspek baik itu respons 
ataupun stimulus. Dalam teori ini menolak tegas adanya pengaruh instinct melainkan semua perilaku hanya menurut pengaruh stimulus dan respons. Pada teori ini ada dua hal prinsip yakni prinsip kebaruan dan prinsip frekuensi. Prinsip kebaruan yakni stimulus baru akan menimbulkan respon yang sama jika diberikan lagi stimulus, namun ketika stimulus diberikan lagi lebih besar dari yang sebelumnya meskipun stimulus yang sama bahkan diberikannya itu di waktu lain atau bahkan waktu lama berselang maka akan menghasilkan stimulus yang lebih besar lagi. Penekanan teori ini yakni perubahan tingkah laku ketika seseorang mampu belajar dalam dirinya dari stimulus yang didapatkan, pada teori ini banyak variasi dalam sudut pandang belajar itu sendiri, sehingga dengan kata lain teori ini berbicara mengenai belajar baru, Behavioristik berpangkal pada beberapa keyakinan tentang martabat manusia, yang sebagian bersifat falsafah dan sebagian lagi bercorak psikologis. Jaenudin (2015:68-70).

\subsection{Teori Kultivasi}

Teori kultivasi menjelaskan mengenai dampak menonton terhadap realitas sosial yang ada pada tayangan mengenai presepsi, sikap dan nilai individu. Teori ini dikemukakan oleh George Gerbner bersama dengan rekan-rekannya tahun 1969. Pada awal penelitian teori ini mempelajari pengaruh dalam menonton televisi dengan tujuan ingin mengetahui bagaimana dunia nyata yang dipresepsikan seorang penonton televisi atau dengan kata lain teori ini berawal dari penelitian yang menekankan adanya "dampak" dari suatu tayangan sehingga membuat presepsi beda antara tayangan dengan dunia nyata yang ada. Nurudin (2004:157).

Teori ini pun menjelaskan suatu presepsi dan keyakinan setiap penonton dengan pembentukan jangka panjang mengenai dunia dari konsumsi tayangan media saja. Fazry M (2014 : 18).

Teori ini memiliki pendapat bahwa media massa mampu menanamkan suatu sikap, dan presepsi tertentu sehingga penonton mampu terpengaruh dan meyakininya berdasarkan seberapa banyak mereka menontonnya. Building Communication Theory, Long Grove: Waveland Press (Infante dkk, 2003: 65).

\subsection{Perilaku Menonton}

Perilaku menonton adalah aktivitas seseorang untuk bereaksi terhadap rangsangan atau stimulus melalui cara melihat pertunjukan, tayangan dengan media massa. Menurut Blumler dalam Little John (Rahayu, 2009 : 28) menjelaskan bahwa perilaku seseorang ataupun audiens dalam menggunakan media massa disebut eksposure media. Terdapat lima indikator eksposure media atau perilaku menonton menurut Frank Biocca dalam "Opposing Conceptions of the Audience: The Active and Passive Hemispheres of Mass Communication Theory, 1988 yaitu:

1. Selectivity (Kemampuan memilih) yaitu kemampuan audiens dalam menetapkan pilihan terhadap media dan isi yang akan di eksposnya.

2. Intentionally (Kesengajaan) yaitu tingkat kesengajaan audiens dalam mengunakan media atau kemampuan dalam mengungkapkan tujuan-tujuan penggunaan media.

3. Utilitarianism (Pemanfaatan) yaitu kemampuan audiens untuk mendapatkan manfaat dari penggunaan media.

4. Involvement (Keterlibatan) yaitu keikutsertaan pikiran dan perasaaan audiens dalam menggunakan media dan pesan media yan diukur melalui frekuensi maupun intensitas.

5. Imprevious to influence yaitu menekankan batasan yang diatur oleh audiens, sehingga audiens tetap "memegang kendali" untuk terpengaruh atau bahkan tidak sebagaimana yang ditentukan oleh pilihan pribadinya.

\subsection{Agresivitas}

Agresi adalah perilaku yang dilakukan oleh seseorang atau kelompok orang dengan tujuan untuk menyakiti orang lain. Menurut Aronson (2010): "Aggresion is intentional behavior aimed at doing harm or causing pain to another person or group". Menurut Buss dan Perry dalam Qian dan Zhang (2014 : 322) agresivitas di identifikasikan melalui indikator-indikator sebagai berikut :

1. Agresi fisik (non verbal), yaitu kecenderungan individu untuk melakukan serangan secara fisik sebagai ekspresikemarahan

2. Agresi verbal, yaitu kecenderungan untuk menyerang orang lain atau memberi stimulus yang merugikan dan menyakitkan orang tersebut secara verbal yaitu melalui kata-kata atau melakukan penolakan

3. Agresi Kemarahan (Angry), yaitu representasi emosi atau afektif berupa dorongan fisiologis sebagai tahap persiapan agresi

4. Agresi Permusuhan (Hostility), yaitu perasaan sakit hati dan merasakan ketidakadilan sebagai representasi dari proses berpikir atau kognitif.

\section{METODE PENELITIAN}

Penelitian ini menggunakan metode penelitian kuantitatif dengan jenis penelitian eksplanatif yaitu merupakan penelitian yang membahas suatu hubungan 
terjadi, perbedaan dan pengaruh antara variabel yang satu dengan variabel lainnya Prasetyo dan Jannah (2014:43).

Dalam penelitian ini menggunakan skala ordinal yakni skala pengukuran yang sudah dapat digunakan untuk menjabarkan peringkat antar tingkatan, tetapi jarak atau interval belum jelas. (Darmawan 2013: 170).

Jenis pengumpulan data pada penelitian ini menggunakan metode survey melalui penyebaran kuisioner. Penilaian untuk masing-masing variabel menggunakan kuisioner dengan skala Likert yakni untuk mengukur sikap, pendapat subjek terhadap suatu objek yang dinyatakan dengan setuju-tidak setuju (Suryadi dkk 2019:156).

Untuk memudahkan pengukuran terhadap kedua variabel maka setiap indikator disusun menjadi instrumen penelitian menjadi bentuk kuisioner dengan menggunakan jawaban skala likert yang akan diajukan kepada responden. Pada penelitian ini, peneliti hanya menggunakan skala empat titik untuk menghindari adanya error central tendency, yaitu responden cenderung memilih jawaban yang sifatnya netral sehingga sulit untuk dianalisis. Populasi adalah wilayah generalisasi yang terdiri dari obyek atau subyek yang memiliki kuantitas dan karakteristik tertentu yang nantinya akan ditetapkan oleh peneliti untuk dianalisis dan ditarik kesimpulannya. (Sugiyono, 2017:61).

Batasan dari populasi penelitian ini ada para remaja SMA di DKI Jakarta. Teknik sampling yang digunakan dalam penelitian ini adalah nonprobability sampling, yaitu quota sampling, dan menggunakan rumus tabel Krejcie-Morgan. Peneliti menggunakan taraf signifikan 90\% dengan ketidaktelitian sebesar $10 \%$ sehingga menghasilkan jumlah sampel minimum yang diperoleh setelah perhitungan dengan rumus yakni sebanyak 100 responden yang terdiri dari 56 perempuan dan 44 laki-laki.

\section{HASIL DAN PEMBAHASAN}

\subsection{Uji Validitas dan Realibilitas}

Sebelum melakukan penyebaran quisioner peneliti melakukan uji validitas dan realibilitas guna untuk menguji konsistensi instrument dan kebenaran konsep serta konstruk yang akan diukur. Uji validitas dan realibilitas pada penelitian ini dibantu dengan menggunakan SPSS versi 23. Suatu kuisioner dikatakan valid jika nilai koefisien korelasi rhitung lebih besar daripada nilai koefisien korelasi rtabel yaitu 0,361 artinya $r$ dikatakan valid, jika $r>0,361$ Sugiyono (2012: 121).

Tabel 1. Hasil Uji Validitas Pada Variabel (X)

\begin{tabular}{|c|c|c|c|}
\hline Item Pertanyaan & r Hitung & r Tabel & Keterangan \\
\hline P1 & 0,713 & 0,3061 & VALID \\
\hline P2 & 0,738 & 0,3061 & VALID \\
\hline P3 & 0,523 & 0,3061 & VALID \\
\hline P4 & 0,470 & 0,3061 & VALID \\
\hline P5 & 0,672 & 0,3061 & VALID \\
\hline P6 & 0,508 & 0,3061 & VALID \\
\hline P7 & 0,689 & 0,3061 & VALID \\
\hline P8 & 0,427 & 0,3061 & VALID \\
\hline P9 & 0,640 & 0,3061 & VALID \\
\hline P10 & 0,524 & 0,3061 & VALID \\
\hline P11 & 0,522 & 0,3061 & VALID \\
\hline P12 & 0,666 & 0,3061 & VALID \\
\hline P13 & 0,722 & 0,3061 & VALID \\
\hline P14 & 0,567 & 0,3061 & VALID \\
\hline P15 & 0,530 & 0,3061 & VALID \\
\hline P16 & 0,622 & 0,3061 & VALID \\
\hline
\end{tabular}

Tabel 2. Hasil Uji Validitas Variabel (Y)

\begin{tabular}{|c|c|c|c|}
\hline Item Pertanyaan & r Hitung & r Tabel & Keterangan \\
\hline P17 & 0,441 & 0,3061 & VALID \\
\hline P18 & 0,493 & 0,3061 & VALID \\
\hline P19 & 0,816 & 0,3061 & VALID \\
\hline P20 & 0,702 & 0,3061 & VALID \\
\hline P21 & 0,622 & 0,3061 & VALID \\
\hline P22 & 0,542 & 0,3061 & VALID \\
\hline P23 & 0,472 & 0,3061 & VALID \\
\hline P24 & 0,561 & 0,3061 & VALID \\
\hline
\end{tabular}

Dari hasil uji validitas diatas menunjukan bahwa setiap item pernyataan mempunyai rhitung lebih besar dari rTabel (0,3061), sehingga semua item pernyataan pada variabel X (Perilaku Menonton) dan Y (Agresivitas) dianggap "Valid".

Realibilitas adalah tingkat konsistensi instrument dalam mengukur apa yang seharusnya diukur. Seperti halnya validitas, realibilitas instrumen juga memerlukan pengujian secara statistik. Suryadi dkk (2019: 188). Menurut nunnally suatu instrument dinyatakan reliabel jika nilai koefesien alfa $>0,70$ Ghozali dalam Suryadi dkk (2019 :188). Untuk menguji reliabilitas kuisioner dalam penelitian ini digunakan software Statistical Program of Social Science (SPSS) versi 23. Berikut hasil uji realibilitas dalam penelitian ini terhadap 30 responden, yaitu: 
Tabel 3. Hasil Uji Realibilitas pada Variabel (X)

\begin{tabular}{|r|r|}
\hline Cronbach's Alpha & N of Items \\
\hline $\mathbf{8 1 5}$ & $\mathbf{1 6}$ \\
\hline
\end{tabular}

Tabel 4. Hasil Uji Realibilitas pada Variabel (Y)

\begin{tabular}{|r|r|}
\hline Cronbach's Alpha & N of Items \\
\hline .767 & $\mathbf{8}$ \\
\hline
\end{tabular}

Dari hasil uji realibilitas menghasilkan penghitungan yang melebihi nilai koefesien alfa yakni 0,70 sehingga diartikan bahwa kedua variabel memiliki realibilitas yang sangat baik.

\subsection{Rekapitulasi tanggapan responden variabel X dan Variabel Y}

Tabel 5. Rekapitulasi Tanggapan Responden

\begin{tabular}{|c|c|c|c|c|}
\hline No.Item & Variabel & $\begin{array}{l}\text { Skor } \\
\text { Total }\end{array}$ & Presentase & Kategori \\
\hline $1 \mathrm{~s} / \mathrm{d} 16$ & Perilaku Menonton & 4869 & $76.07 \%$ & Tinggi \\
\hline $17 \mathrm{~s} / \mathrm{d} 24$ & Agresivitas & 2356 & $73.63 \%$ & Tinggi \\
\hline \multicolumn{2}{|c|}{ Jumlah Skor Total } & & 7225 & \\
\hline \multicolumn{2}{|c|}{ Presentase Skor } & $75.26 \%$ & & \\
\hline
\end{tabular}

Tabel diatas merupakan gambaran rekapitulasi tanggapan responden tentang Variabel $\mathrm{X}$ dan Variabel $\mathrm{Y}$ Berdasarkan pengolahan data diatas, maka dapat dilihat skor variabel $(\mathrm{X})$ dan variabel $(\mathrm{Y})$ adalah 7225 , dengan presentase sebesar $75.26 \%$.

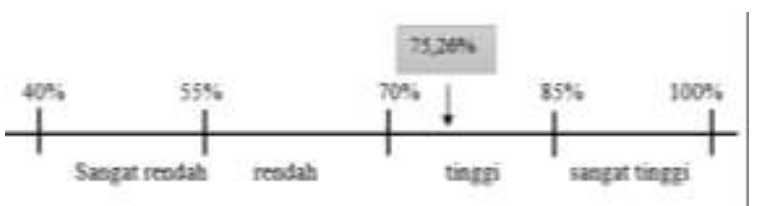

Gambar 3. Presentase garis kontinum variabel $(\mathrm{X})$ dan variabel (Y)

Secara ideal, skor yang diharapkan untuk responden terhadap 24 pernyataan adalah 9600 atau $100 \%$. Dari perhitungan dalam tabel, nilai yang ditunjukkan adalah 7225 dari 9600. Dengan demikian, dapat disimpulkan bahwa kedua variabel berada dalam kategori Tinggi.

\subsection{Uji Normalitas}

Uji Normalitas merupakan salah satu bagian dalam Uji Asumsi Klasik yang memiliki fungsi sebagai penguji apakah diantara regresi variabel Independen dan Dependen sama sama memiliki distribusi data yang normal atau tidak. Pada Uji Normalitas, peneliti memperhatikan pendistribusian data melalui Grafik
Normal dari P-P Plot. Hasil penelitian ini akan dianggap normal apabila grafik yang ditampilkan semakin berbentuk lurus. Selain itu, Uji Normalitas juga bisa dilihat dari table test of normality dengan menggunakan Kolmogorov Smirnov. Jika dalam tabel mendapatkan nilai signifikan lebih besar dari pada 0.1 , maka distribusinya akan normal. Berikut ini merupakan hasil perhitungan Uji Normalitas menggunakan P-P Plot dan juga Histogram.

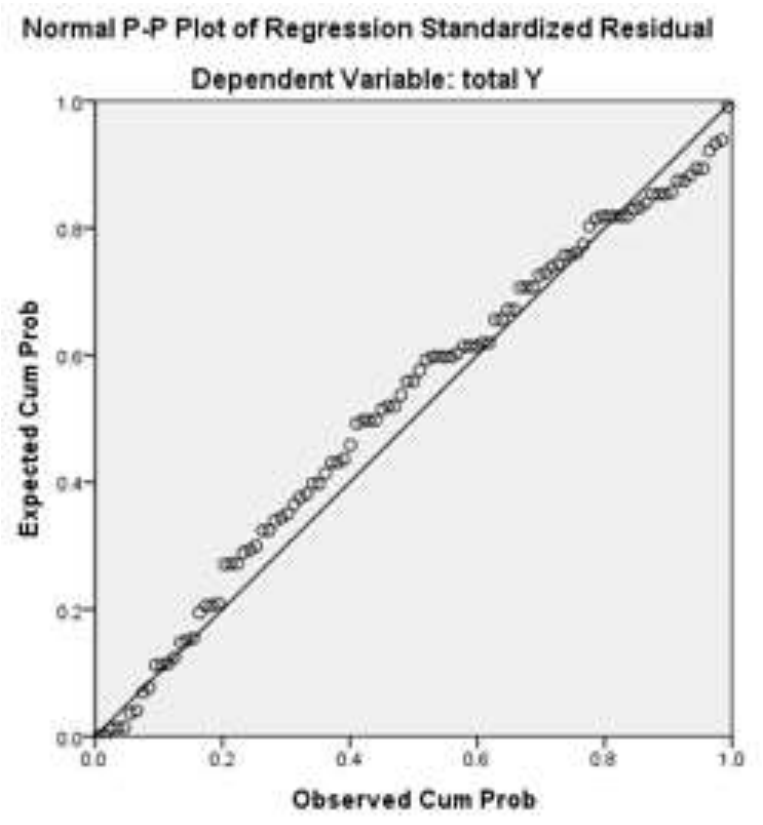

Gambar 4. Hasil Uji Normalitas P-Plot

Berdasarkan hasil uji normalitas menghasilkan data yang bisa dinyatakan terdistribusi normal, karena data atau titik menyebar disekitar garis diagonal dan mengikuti arah garis diagonal.

\subsection{Analisis Korelasi}

Untuk mengetahui hubungan antara perilaku menonton dan agresivitas, maka peneliti menggunakan analisis korelasi pearson. Berikut ini merupakan hasil olahan dari software SPSS23 for windows untuk mengetahui korelasi hubungan antara perilaku menonton tayangan kekerasan dalam film Joker terhadap sikap agresivitas penonton remaja di DKI Jakarta.

Tabel 6. Analisis Korelasi Pearson

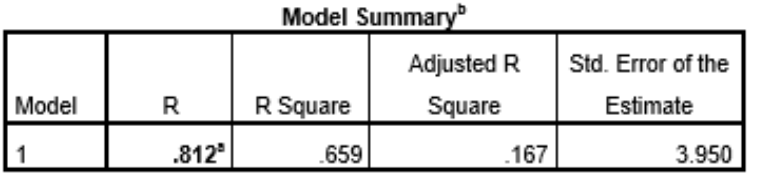

a. Predictors: (Constant), Perilaku Menonton (X)

b. Dependent Variable: Agresivitas $(\mathrm{Y})$ 
Berdasarkan tabel diatas diperoleh nilai koefisien korelasi (r) sebesar 0.812 atau $81,2 \%$ yang berarti terdapat hubungan yang kuat antara perilaku menonton dengan agresivitas penonton remaja di DKI Jakarta.

\subsection{Koefisien Determinasi}

Koefisien determinasi dilambangkan dengan $\mathrm{r} 2$, yaitu nilai-nilai yang menyatakan proporsi variasi keseluruhan dalam nilai variabel dependen yang dapat diterangkan, atau dengan kata lain diakibatkan oleh hubungan linear dengan variabel independen. Selain itu sisanya diterangkan oleh variabel yang lainnya (Supardi, 2016:188). Setelah diketahui nilai korelasi sebesar 0,812 dari penghitungan SPSS 23, maka koefisien determinasi dapat dihitung menggunakan rumus sebagai berikut:

$$
\mathrm{KD}=\mathrm{R}^{2} \times 100 \%=(0,812)^{2} \times 100 \%
$$

Dengan demikian, maka diperoleh nilai koefesien determinasi sebesar 65,93\% yang menunjukan arti bahwa perilaku menonton memberikan pengaruh terhadap agresivitas. Sedangkan sisa dari perhitungan tersebut yaitu sebesar $34,07 \%$ diartikan bahwa Agresivitas dipengaruhi oleh variabel lain yang tidak diamati di dalam penelitian ini.

\subsection{Analisis Regresi Linier Sederhana}

Analisis regresi linier sederhana pada penelitian ini digunakan untuk menganalisa variabel yang digunakan, dalam hal ini adalah perilaku menonton tayangan kekerasan sebagai variabel independent atau variabel $\mathrm{x}$, dan agresivitas sebagai variabel dependen atau variabel y. Berdasarkan hasil olahan data yang telah dilakukan oleh peneliti, maka diperoleh hasil sebagai berikut:

Tabel 7. Persamaan regresi linier sederhana

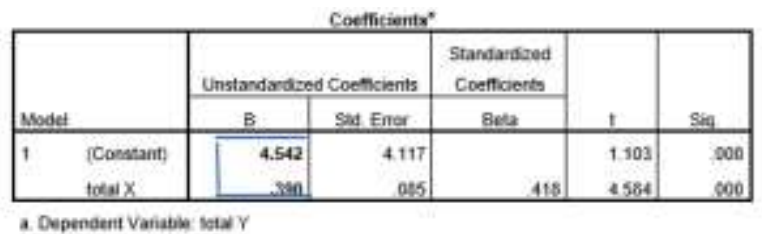

Berdasarkan hasil olahan software SPSS23 for windows, diperoleh model linier regresi sederhana sebagai berikut:

$$
\mathrm{Y}=4.542+0.390 \mathrm{X}
$$

Dari persamaan berikut memiliki arti bahwa nilai konstanta a memiliki arti bahwa apabila perilaku menonton (X) bernilai nol atau perilaku menonton tidak dipengaruhi oleh variabel agresivitas (Y), maka nilai rata-rata perilaku menonton $(\mathrm{X})$ adalah 4.542 . Sedangkan, koefisien regresi $\mathrm{b}$ memiliki arti bahwa apabila variabel perilaku menonton $(\mathrm{X})$ meningkat sebesar satu satuan, maka nilai agresivitas (Y) akan meningkat sebesar 0,390. Koefisien regresi tersebut bernilai positif, yang artinya perilaku menonton tayangan kekerasan memiliki pengaruh positif terhadap agresivitas penonton remaja di DKI Jakarta.

Karena hasil regresi bernilai positif dimana perilaku menonton tayangan kekerasan memiliki pengaruh terhadap agresivitas hal tersebut menguatkan teori yang digunakan yakni teori kultivasi dimana remaja yang menonton film joker lebih dari dua kali meskipun dengan media yang berbeda mampu memberikan pengaruh dari tayangannya, sesuai dengan asumsi teori tersebut yaitu media massa mampu menanamkan suatu sikap, dan presepsi tertentu sehingga penonton mampu terpengaruh dan meyakininya berdasarkan seberapa banyak mereka menontonnya.

\section{KESIMPULAN DAN SARAN}

\subsection{Kesimpulan}

Berdasarkan hasil penelitian dan analisis data yang telah dilakukan oleh peneliti, maka mampu didapatkan beberapa kesimpulan yang mampu digunakan untuk menjawab rumusan masalah. Diantara adalah sebagai berikut:

1. Berdasarkan hasil perhitungan Uji Hipotesis didapatkan bahwa T Hitung lebih sebesar 4.584 lebih besar dibandingkan T Tabel sebesar 1.664 ditambah dengan nilai signifikan sebesar 0.000 yang lebih kecil dari 0.1 sehingga didapatkan $\mathrm{Ha}$ Diterima dan Ho Ditolak serta posisi $\mathrm{T}$ dalam grafik masuk dalam area positif sehingga sudah dipastikan bahwa "Terdapat Pengaruh Perilaku Menonton Tayangan Kekerasan dalam Film Joker terhadap Agresivitas para Penonton Remaja di DKI Jakarta" sehingga dari sini pun didapatkan persamaan regresi yaitu $\mathrm{Y}=4.542+0.390 \mathrm{X}$.

2. Dalam mengetahui seberapa besar signifikan pengaruhnya maka didapatkan perhitungan bahwa 65.93\% Perilaku Menonton Tayangan Kekerasan (X) berpengaruh terhadap Agresivitas para penonton remaja di DKI Jakarta. Sedangkan sebesar $34.07 \%$ dipengaruhi oleh variabel lain yang tidak diukur dalam penelitian ini.

Hasil dari penelitian ini pun menunjukkan bahwa Agresivitas penonton remaja di DKI Jakarta diantaranya dipengaruhi cukup besar oleh perilaku menonton 
tayangan kekerasan hal ini terlihat dari hasil penelitian yang didapatkan dengan responden yang digunakan yakni remaja sma di Jakarta yang sudah menonton film Joker lebih dari satu kali. Sehingga hal ini sejalan dengan teori yang digunakan dalam penelitian ini yakni teori kulitivasi, yang berasumsi bahwa media massa mampu menanamkan suatu sikap, dan presepsi tertentu sehingga penonton mampu terpengaruh dan meyakininya berdasarkan seberapa banyak mereka menontonnya.

\subsection{Saran}

\section{A. Praktis}

Berdasarkan hasil penelitian, untuk peneliti selanjutnya diharapkan dapat menggunakan model analisis yang lain agar hasil penelitiannya dapat dianalisis lebih mendalam lagi sehingga dapat melengkapi kekurangan dari penelitian ini.

\section{B. Teoritis}

1. Dari hasil penelitian ini diharapkan untuk para remaja yang menjadi target penelitian untuk bisa memilah tayangan yang mereka liat dan bisa mamastikan sesuai dengan kapasitas dan umur masing-masing.

2. Saran bagi penyiar film seperti bioskop agar mampu memberikan regulasi yang ketat menyesuaikan dengan rating film yang sedang tayang seperti mengecek kartu identitas penonton, sehingga usia yang tidak sesuai dengan rating film tidak bisa untuk menontonnya.

\section{DAFTAR PUSTAKA}

Ardianto, Elvinaro dkk. (2015). Komunikasi Massa: Suatu Pengantar. Bandung: Simbiosa Rekatama Media.

Arikunto, S. (2013). Prosedur Penelitian: Suatu Pendekatan Praktik. Jakarta: Rineka Cipta.

Bambang Prasetyo dan Lina Miftahul Jannah. 2014. Metode Penelitian Kuantitatif Teori dan Aplikasi. Jakarta: Rajawali Pers

Bungin, Burhan. (2010). Metodologi Penelitian Kuantitatif. Jakarta: Kencana Prenada Media Group.

Buss \& Perry. (1992). The Aggression Questionnaire. Journal of Personality and Social Psychology: The American Psychological Association, Inc.
Danim, Sudarwan. (2004). Motivasi Kepemimpinan \& Efektivitas Kelompok. Jakarta: PT Rineka Cipta.

Edi, Suryadi dkk. (2019). Metode penelitian komunikasi dengan pendekatan kuantitatif. Jakarta: Penerbit PT. Remaja Rosdakarya

Haryatmoko. (2007). Etika Komunikasi (Manipulasi Media, Kekerasan, dan Pornografi). Yogyakarta: Kanisius.

Infante, D. A., Andrew S., Rancer \& Deanna F.W., (2003), Building Communication Theory, Long Grove: Waveland Press.

Nurudin, (2004). Komunikasi Massa. Malang: CESPUR.

Rustan, Ahmad. (2018). Pola Komunikasi Orang Bugis: Kompromi antara Islam dan Budaya Yogyakarta: Pustaka Pelajar.

Sugiyono. (2012). Metode Penelitian Kuantitatif Kualitatif dan $R \& D$. Bandung: Alfabeta.

Sugiyono. (2009). Metode Penelitian Kuantitatif, Kualitatif dan $R \& D$, Bandung: Alfabeta.

Sugiyono. (2017). Metode Penelitian Pendidikan Pendekatan Kuantitatif, Kualitatif, dan $R$ \& $D$. Bandung: Alfabeta.

Ujam, Jaenudin. (2015). Teori-teori Kepribadian. Bandung:CV Pustaka Setia

Wiryanto. (2000). Teori Komunikasi Massa. Jakarta: Gramedia Widiasarana Indonesia.

Biocca, F. A. (1988). Opposing Conceptions of the Audience: The Active and Passive Hemisphere of Mass Communication Theory. University of North Carolin: Chapel Hill.

Farhatilwardah. (2015). Pengaruh Menonton Film dan Bermain Video Game Kekerasan Terhadap Perilaku Agresi Siswa SMP di Perdesaan Bogor. Institut Pertanian Bogor.

M.Fazry. (2014). Pengaruh Tayangan Kekerasan Dalam Film Kartun Terhadap Perilaku Agresif Anak di SDN 108 Bukit Raya Pekanbaru. Universitas Islam Negeri Sultan Sarif Kasim Riau

Qian \& Zhang. (2014). The effects of viewing violent movie via computer on aggressiveness among college students Department of Psychology. Southwest University: Chongqing, China.

Rahayu, Nuryani Tri. (2009). Tayangan Hiburan Tv dan Penerimaan Budaya Pop. FISIP Universitas Veteran Bangun Nusantara. 
https://databoks.katadata.co.id/datapublish/2019 102/25/bekraf-targetkan-penonton-bioskop2019-tumbuh-15 diakses pada tanggal 31 Januari 2020 pukul 09.38 WIB

https://www.idntimes.com/hype/entertainment/ve nita-beauty-1/dipimpin-joker-10-film-

rating-dewasa-dengan-pendapatan

tertinggi/1(diakses tanggal 27 Januari 2020 pukul 12.50 WIB)

https://bankdata.kpai.go.id/tabulasidata/datakasus-dari-media-cetak/data-kasusanak- berdasar-pemantauan-media-cetak-2016

dan olahan peneliti (diakses pada tanggal 27 Maret 2020 pukul 17.25 WIB).

http://filmindonesia.or.id/ (diakses tanggal 27 Januari 2020 pukul 19.44 WIB).

https://www.idntimes.com/hype/entertainment/ve nita-beauty-1/dipimpin-joker-10-filmratingdewasa-dengan-pendapatan-tertinggi

(diakses tanggal 27 Januari 2020 pukul $12.50 \mathrm{WIB})$. 